marriages, and of sons who had four or more brothers or sisters, and found that :-

\begin{tabular}{|c|c|c|c|}
\hline & $\begin{array}{l}\text { Wifdren per } \\
\text { marriage. }\end{array}$ & $\begin{array}{l}\text { Sons to Ioo } \\
\text { Daughters. }\end{array}$ & Sterile. \\
\hline & $4^{\circ} 09$ & I 16 sons & 8.4 per cent. \\
\hline nary families & $3 \cdot 8$ & 97 sons & $18 \cdot 5$ \\
\hline e families.. & $3 \cdot 8$ & 110 sons & I $2 \cdot 4$ \\
\hline
\end{tabular}

These results point rather to the conclusion that could have been surmised: only sons being usually better off, have no reason to restrict the size of their families, as is so often necessary where a fortune has to be divided among many, and hence they have larger families.

Adding the three separate parental classes together, we have :- -

Sons to 100

$434 \mathrm{~F}$. and M. only children $\dddot{\text { F. and }} \mathrm{M}$. or $265 \mathrm{~F}$. and $\mathrm{M}$. ordi$75^{\circ} \mathrm{F}$. and $\ddot{M}$. large families $\ldots . . .$. Sons. 912 $5 \mathrm{I} 4$ 776 I688 er marr. aughters.

$$
57 \text { I } 2
$$

Which shows that the number of children per marriage is so nearly similar that with a larger number of marriages to deal with they would probably be the same. Comparing the figures in the last column brings forth the most curious result of the investigation, that the marriages of members of ordinary sized families have a smaller proportion of sons to daughters than in the case of the other marriages.

The size of the families of the various classes dealt with may prove of interest, although nothing of great importance can apparently be drawn from the figures. The table contains the percentage of children per hundred marriages :-

Number of family.

$$
\text { Sterile. }
$$

Marriages of-

Only female child

Only male

Ordinary ...

$$
\underset{\circ}{\text { Sterile. }} \quad 1,2 \quad 3,4 \quad 5,6 \quad 7,8 \quad 9 \text { \& over. }
$$

\begin{tabular}{|c|c|c|c|c|c|c|c|}
\hline & & & & & & & \\
\hline tal & & & 64 & 123 & I I 7 & 95 & 54 \\
\hline Averag & . & $\cdots$ & $12 \cdot 3$ & $10^{\circ} 2$ & $9 \cdot 7$ & 8 & $4 \cdot 5$ \\
\hline
\end{tabular}

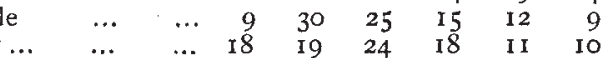

$\begin{array}{lllllllr}\text { Son of large families } & . . & \text { I } 2 & 26 & 25 & 18 & 10 & 8\end{array}$

And, now, what are the final results to be drawn from the foregoing analysis? That, as a matter of fact, there is in no case a difference of sufficient magnitude to enable us to say that the fertility of either male or female in the human race is in any way correlated to the fertility of their fathers or mothers, and a fortior $i$ correlated to the fertility of their grandparents.

Churchfield, Edgbaston.

F. Howard Collins.

\section{"A Short History of Scientific Education."}

IN Sir Norman Lockyer's address, under the above title, reprinted in NATURE of October 13 , he is reported to have said : "Before the Reformation the universities were priestly institutions, and derived their authority from the Fopes. The universities were for the few ; the education of the people, except in the various crafts, was unprovided for. The idea of a general education in secular subjects at the expense of the State or of communities is coeval with the Reformation. In Germany, even before the time of Luther, it was undreamt of, or rather, perhaps, one should say, the question was decided in the negative.". . "With the Reformation this idea spread to France."

The whole passage seems to have been taken from that travesty of "The History of Pedagogy" compiled by Dr. Gabriel Compayré (compare pp. II4-II5 and 120), and it is unfortunate that Sir Norman Lockyer should have followed so untrustworthy a guide.

For the statements contained in the above-quoted sentences are in direct opposition to the facts as ascertained by the best authorities in the matter. It is quite true that education owes much to the bishops and monks of the centuries before the Reformation, for it was in the episcopal seminaries, which formed a part of the bishop's own household, and in the great monastic schools, such as those of Cluny, Bec, St. Gall, and numerous others, that the torch of learning was kept alight in the troublous times when the laity were mostly fighting to resist the incursions of barbarians, or warring one with the other.

The priestly infiuence was therefore an influence for good. More than this, such Popes as Innocent III., Honorius III., Benedict XII., Gregory IX., Urban IV., to name no others, deserve the gratitude of mankind of all ages for their persevering efforts to improve the state of learning in the schools and universities of their times. Sir Norman Lockyer tells us that the " universities were for the few." How is this statement to be reconciled with the fact that students flocked to the universities in the days before the Reformation in multitudes so great, that we find it reported, that in the thirteenth century some ten thousand scholars attended the classes of the University of Bologna at one time, with another forty thousand at Paris, and thirty thousand at Oxford, while at Bordeaux a single college boasted of upwards of two thousand scholars. Even allowing that the numbers are exaggerated, it is indisputable that in this century the universities were crowded with students. Nor were these scholars all clerics, nor yet the sons of the nobles and well-to-do citizens, but mostly poor men-a scholar and a poor man being almost synonymous terms. Does not our own Chaucer describe the Clerk of Oxenford as "full hollow and threadbare?" And this, too, at a period when printed books were either altogether wanting or were a rarity. The number of universities founded in Europe in pre-Reformation days has been reckoned as sixty-six.

And what is true of universities is true also of elementary and grammar schools. In this connection, the first essay of John Charles Tarver's collection, "Debateable Claims," is worth referring to. "Fifty years ago," he writes, "the Reformation was popularly regarded as the very first beginning of enlightenment. $U_{p}$ to that time a crass and brutish ignorance was supposed to have prevailed . . . Since the middle of this century this view of our history has been considerably modified ... How were the middle classes taught before the Reformation? The popular view is that they were not taught at all till Henry VIII. and his children, especially Edward VI., reserved something from the spoils of the Church endowments for grammar schools. A more enlightened view holds that incidentally the monasteries themselves were teaching establishments, and especially that the friars were not only preachers, but teachers... we should hardly have expected to find that the period of the Reformation was a period of indifference to schools; it was more than that, it was a period when schools were suppressed " And further on: "Again, the Reformation in its later stages was distinctly an upheaval of ignorance : the value of the old methods of teaching was not understood; 'the baser sort,' armed with the text of the Bible, thought all other learning superfluous; they regarded it, as classical learning is regarded by the scientific smatterer of to-day, as antiquated and superstitious. In Germany, according to Dr. Scherer, this attitude of mind contributed to the Counterreformation; for contempt of learning having destroyed the teachers, when in the fulness of time the want of them was felt, the Jesuits were ready to take their place." In Mr. Leach's "English Schools at the Reformation," we learn that in England about the year 1546 there was one grammar school for every 8000 people, instead of one for every 23,000 as was the case in 1865 ; so that, at least in England, it is not correct to state "that the education of the people was unprovided for."

And what is true of England is true of other countries. As a set-off to the reference made by Sir Norman Lockyer to Luther's laudable endeavours in the carse of free education for the people, let us take the following quotation from a decree drawn up in the days of the Anglo-Saxons. "Mass-priests shall always have in their houses a school of learners; and if any good man will trust his little ones to them for lore, they shall right gladly receive and kindly teach them.... They shall not, however, for such lore, demand anything of the parents, besides that which the latter may give of their awn will." This decree first appears in the Council of Vaison, and re-appears in the acts of several Councils of England, France, and Italy : for instance, in the Carlovingian Council of Orleans, and in the Constitutions of Vercelli. The request of the States General of Orleans in 1560 to Francis II., quoted by Sir Norman Lockyer, is therefore nothing new in the matter of free education. In addition to the Constitutions of Vercelli, those of Dado of Verden, and Heraclius of Liege, ordain the establishment of "little" or parochial schools, wherein poor children of both sexes, about the age of seven years, are to be tainght gratis. That free

NO. 15 I 4 , vOL. 59] 
schools existed in England before the Reformation, as for instance those at Wisbech, Week St. Mary, Wimborne, Dar lington, and Chipping Campden, appears from Mr. Leach's researches before referred to ( $\mathrm{pp}$. I IO-I I4). In fact, the very idea of receiving payment for teaching was scouted until the introduction of secular teachers about the beginning of the eleventh century.

And yet Sir Norman Lockyer speaks of "the iron heel of priestcraft"-an ugly word-as arresting the "new spirit" presumably of free education of the people. Nor is his uncomplimentary reference to the Jesuits in France more according to facts. However what the Society of Jesus has effected for the cause of education, both literary and scientific, is too patent to any unbiassed student of the history of education to. need discussion. Moreover, I should be needlessly occupying space in this journal.

Stonyhurst College, October 23.

\section{Organic Variations and their Interpretation.}

I Hope you will allow me to correct two serious errors in Prof. Weldon's reply to my criticisms.

I was never foolish enough to assert, as he implies that I did, that the theory of natural selection attempts to answer the question whether modifications originate accidentally or not. I said that this was the question between the adherents of the theory and its opponents. I quite agree with Prof. Weldon that the theory of natural selection does not involve a theory of the origin of variations. For that reason it is not by itself a theory of evolution.

Prof. Weldon asserts that I said there was no evidence of the entrance of fine mud into the gill-chambers of crabs during life. I said, or wrote, nothing of the kind. He found china clay in the gill-chambers of the individuals which died in his experiments, and I poirted out that this was no proof that the crabs had died because their branchial apparatus was unable to keep out the particles of clav. The clay was not found in the gills of the survivors, and he inferred that they owed their survival to more efficient filtration, due to their relatively narrower frontal breadths. I merely pointed out that the inference was not valid because the dead crabs had been in the muddy water after death, while the survivors were killed after removal.

I do not admit that Prof. Weldon has successfully vindicated his evidence or his conclusions against my criticisms; but as you, Sir, are unable to allow me any more space, I must thank you for printing my first letter, and leave further discussion of the matter for some other opportunity.

Penzance, October 22.

J. T. Cunningham.

\section{SCIENTIFIC EDUCATION IN RURAL DISTRICTS.}

$\triangle M O N G$ the problems of technical education which A County Councils have had to face, the most difficult is the bringing home of the importance of scientific training to those engaged in agriculture and in rural industries generally. A study of the results achieved in the various counties very clearly brings out the fact that while considerable progress has been made in manufacturing centres where the practical bearing of science is more or less obvious, the agricultural counties have hitherto failed to show a similar progress as the outcome of their efforts to improve the rural industries. Many causes are contributing in this country to check advancement in rural technical education. The general depression of agriculture, the conservatism and apathy of farmers and landowners, the high cost of carriage of farm produce, and the incompetence of technical instruction committees are among these causes; but it would be out of place to discuss such matters in the columns of a scientific journal, and we are content in admitting that the technical committees in agricultural districts have had a far more difficult task imposed upon them than the committees of urban manufacturing centres have ever been called upon to perform.

In bringing under the notice of the readers of NATURE an educational movement which we are firmly persuaded

$$
\text { NO. I } 514 \text {, VOL. 59] }
$$

is a movement in the right direction, we have primarily in view the fact-obvious to men of science, but, unfortunately, not so obvious to those more immediately concerned-that agriculture in its widest sense is as much dependent upon scientific research for its advancement as any other industry. The great importance attached to agricultural stations in the United States and Canada, and on the continent, and the splendid results in the way of agronomic research which are being achieved at these stations, amply testify that other countries are alive to their agricultural welfare. All that has been done in this country by those great pioneers, Lawes and Gilbert, has been the result of private munificence.

In view of the fact that the results of scientific research are bound with the progress of time to make themselves more and more felt in all kinds of rural industries, and bearing in mind also the slow rate of development in this direction in our country, we are convinced that the best chance of enabling our agricultural population to appreciate the importance of research and to meet competition is to give the rising generation an opportunity of acquiring some knowledge of sound scientific principles as a part of their early training. If the present generation of farmers and landowners cannot or will not bend to the inevitable, and endeavour to cope with difficulties by scientific method, then, at any rate, let facilities be given to their children for the acquisition of such scientific habits of mind as will enable them, without actually becoming experts in any particular science, to realise exactly how they are situated with respect to their competitors. It is hardly necessary to point out in these columns that in all rational schemes of technical education this principle is recognised as sound. It is remarkable, in view of this acknowledged principle, that so many technical instruction committees should have attempted to begin their work at the wrong end, and should have expended large sums in encouraging sporadic teaching by specialists to adults who, for lack of proper training, are totally unprepared for specialisation in any direction. In most cases a critical analysis of the results obtained under this system shows that unintelligent manual dexterity is the utmost that can be achieved. This, in our view, does not constitute technical education; certainly, so far as agricultural industry is concerned, this kind of instruction is not likely to be of any permanent value.

The agricultural industries may be regarded as furnishing a rallying point round which several distinct branches of science meet. To insure success in such occupations when all the resources of science are being utilised by our competitors, it is becoming more and more imperative that the education of the farmer should, at any rate, be placed on a scientific foundation. We cannot, unfortunately, look at present to the elementary schools for any help in this matter. The children leave too early in life, and such science teaching as they receive (if any) is quite inadequate. The sporadic system encouraged by some County Councils has already been condemned. Still more unfortunate appears to us to be the frittering down policy of administering the technical education grant in the form of doles to districts in proportion to the number of the inhabitants. The few want educating in the thinly populated agricultural districts quite as much, or even more, than the many in the towns. It is more costly to educate the few than the many; therefore the rural districts require more financial aid proportionally than the towns. Under the system referred to, the country districts get less. If an "intelligent foreigner," who came over to inquire into our educational systems since the passing of the Technical Instruction Act, were told that the degree and quality of the education given to a boy or girl had been made dependent on the number of inhabitants per square mile

1 The fructicultural station established by the Duke of Bedford and Prof Pickering at Ridgmount also comes under this heading 